\title{
DAMPAK LIBERALISASI EKONOMI TERHADAP HUKUM PERTANAHAN DI INDONESIA
}

\author{
Musleh Herry \\ Fakultas Syari'ah UIN Maliki Malang \\ Telepon: (0341) 559399 \\ Email:el.moehy77@gmail.com
}

\begin{abstract}
The developmental program of the government creates delicate issues concerning the proper allocation of land. While the government program of welfare necessitates the availability of land to build housings, roads, factories and business centers, the plight of society displaced from their land should not be overlooked. Liberalist approach on managing land proves to bring more problem than solution to the society at large. Through the strong capital and wide network in executive and legislative bodies, the liberalist proponents manage to seize huge amounts of land at the expense of the original owners, mostly villagers who lack of apprehension about the price of land. The vague regulation concerning land also contributes to the handover of huge acres of land from the villagers to the capital owners. Without government intervention on the land market, it is worried that the process of land acquisition by the capital owner will run out of control.

Program pembangunan pemerintah memunculkan masalah seputar penguasaan tanah. Sementara di sisi lain program pemerintah untuk kesejahteraan membutuhkan ketersediaan tanah untuk membangun perumahan, jalan, pabrik pusat -pusat bisnis. Persoalan berat kepemilikan tanah yang dihadapi masyarakat harus mendapat perhatian.Pendekatan kelompok liberal terhadap pengaturan penguasaan tanah menimbulkan banyak persoalan bagi masyarakat secara luas. dengan menggunakan modal yang besar dan jaringan yang kuat di lembaga eksekutif dan legislatif, pendukung kelompok liberal mengambil alih kepemilikan tanah secara besar-besaran terutama dari penduduk desa yang tidak mengetahui harga tanah yang semestinya. Peraturan yang masih belum jelas berkaitan dengan tanah juga menyebabkan pindah kepemilikan dari petani ke pemilik modal. Tanpa intervensi dan kontrol dari pemerintah terhadap pemasaran tanah, dikhawatirkan persoalan penguasaan tanah oleh pemilik modal akan lepas kontrol.
\end{abstract}

Keywords: Liberalisasi Ekonomi, Penguasaan Tanah, Hak Milik

\section{Pendahuluan}

Tanah bagi kehidupan manusia mempunyai arti yang sangat penting, karena sebagian besar kehidupan memerlukan tanah. Manusia membutuhkan tanah dan hasilnya untuk kelangsungan hidup, tempat pemukiman dan usaha; bahkan ketika meninggal sekalipun manusia masih membutuhkan sepetak tanah. Disamping itu tanah dapat dinilai sebagai harta yang mempunyai sifat permanen, karena ia memberikan kemantapan untuk dicadangkan bagi kehidupan di masa mendatang. ${ }^{1}$ Bagi sebuah negara agraris, tanah mempunyai fungsi yang amat penting bagi kemak-

1 Abdurahman, Masalah Pencabutan Hak-Hak Atas Tanah dan Pembebasan Tanah di Indonesia (Bandung: Citra Aditya Bakti, 1991), h. 45. 
muran dan kesejahteraan rakyat. Kenyataannya, luas tanah dalam sebuah negara adalah terbatas, terutama lahan pertanian, sementara jumlah penduduk semakin bertambah.

Sebagai sebuah negara berkembang dengan tingkat pertumbuhan penduduk yang tinggi, Indonesia menghadapi permasalahan tentang ketersediaan tanah untuk pembangunan dan lahan hunian penduduk. Untuk itu bisa dikatakan bahwa keberhasilan pembangunan sangat ditentukan oleh kemampuan pemerintah dalam mengelola aspek pertanahan termasuk bagaimana manajemen pemerintah dalam menghadapi masuknya arus liberalisasi ekonomi dan dampaknya terhada penguasaan tanah.

\section{Konsepsi Liberalisasi Ekonomi dan Dam- paknya Bagi Ekonomi Suatu Negara}

Liberalisasi bukanlah liberalisme. Pandangan hidup, ideologi dan falsafah kita masih tetap Pancasila, hanya saja kita bersedia membuka diri terhadap masuknya barang, jasa dan modal asing sebagaimana telah dilakukan oleh negara lain sebagai konsekuensi pemberlakuan GATT di Indonesia. ${ }^{2}$ Barang, jasa dan modal asing tersebut dimungkinkan untuk masuk dan keluar dari negara kita tanpa hambatan, baik berupa tarif maupun nontarif. Apabila era liberalisasi ekonomi yang telah berkembang ke arah global ini tidak kita antisipasi, dikhawatirkan perkembangan perekonomian dan perdagangan kita akan terhambat.

Keterbukaan tersebut dapat meningkatkan nilai ekspor Indonesia karena ekspor kita dapat memasuki negara lain tanpa mengalami kesulitan. Hanya saja kita harus meningkatkan daya saing agar memperoleh tempat di pasaran luar negeri. ${ }^{3}$ Pada tingkat nasional, li-

2 Harsono, Boedi. 1999. Undang-Undang Pokok Agraria, Sejarah Penyusunan, Isi dan Pelaksanaannya (Bagian Pertama, Jilid kesatu). Jakarta: Djambatan, h. 357.

3 Suyono, 1995. Peranan dan Strategi Pengembangan Tanah (Land Developers) dan Birokrasi dalam Mengantisipasi Dampak Liberalisasi Ekonomi Terhadap Penguasaan Tanah Terutama Untuk Pemukiman Berskala Besar. Makalah Seminar Nasional Kebijakan Pertanahan dan Liberalisasi Ekonomi, Fakultas Huku m, UGM, Yogyakarta, h. 1. beralisasi ekonomi memperbesar peran swasta dalam pembangunan, sedangkan peran pemerintah adalah sebagai fasilitator, pengatur, pengarah dan pembina bagi terciptanya kondisi yang kondusif bagi investasi swasta. Pemerintah hanya menangani hal-hal yang belum dapat diserahkan kepada pihak swasta atau yang berkaitan dengan hajat hidup orang banyak.

Masuknya modal asing dan semakin besarnya peran swasta akan meningkatkan pertumbuhan ekonomi Indonesia yang tentu saja akan meningkatkan pendapatan nasional dari sektor pajak. Selain itu, investasi asing dan swasta akan membuka kesempatan kerja yang luas sehingga dapat mengurangi jumlah pengangguran dan berbagai kerawanan sosial yang mengikutinya.

Liberalisasi ekonomi ternyata tidak hanya memberikan keuntungan tapi juga membawa dampak yang merugikan, khususnya dalam bidang penguasaan tanah. Akibat liberalisasi ekonomi, distribusi penguasaan tanah dan penentuan harga tanah menjadi lebih bergantung pada mekanisme pasar, yang menjadi ciri liberalisasi ekonomi. Harga tanah sepenuhnya akan ditentukan oleh pembeli dan penjual berdasarkan kesepakatan di antara keduanya. Sementara itu, diantara para calon pembeli akan terjadi persaingan memperebutkan lokasi-lokasi strategis sehingga harga tanah akan meningkat.

Konsekuensi lain dari liberalisasi ekonomi adalah kewajiban pemerintah untuk menyediakan tanah yang diperlukan bagi investtasi maupun pembangunan lainnya. Karena jumlah tanah yang dikuasai negara semakin sedikit, tanah rakyat harus digunakan untuk keperluan pembangunan. Hal itu tentu saja berdampak pada kurangnya akses rakyat terhadap tanah, baik di pedesaan maupun di perkotaan.

Di wilayah pedesaan penguasaan tanah hak milik masyarakat, baik secara terang-terangan maupun tersamar, baik oleh perseorangan, swasta maupun pemerintah, juga semakin meningkat seiring dengan meningkatnya pelaksanaan pembangunan berbasis liberalisasi ekonomi. Proses penguasaan tanah di pedesaan terjadi karena alasan berikut: penye- 
barluasan pembangunan dan hasil-hasilnya, dan masih murahnya harga tanah di pedesaan karena masyarakat pedesaan belum banyak mengerti tentang harga tanah di pasaran.

Sebagai sebuah undang-undang produk bangsa Indonesia UUPA dibuat untuk mensejahterakan rakyat. Dengan adanya UUPA masyarakat Indonesia, terutama yang tinggal di pedesaan yang sebagian besar berprofesi sebagai petani, diharapkan semakin sejahtera dengan penataan system penguasaan tanah dan penggunaan tanah yang ada. Namun, pada kenyataannya, masyarakat pada umumnya semakin sulit atau sengsara, karena pengaturan dan penguasaan tanah telah menyimpang dari ketentuan yang ada, dan masyarakat, terutama yang tinggal di pedesaan, akan semakin sulit jika implementasinya dibiarkan berlarut-larut. Ditengarai, ada orangorang tertentu atau badan hukum yang menguasai lahan pertanian untuk kepentingan bisnis dengan sistem hak milik, sewa maupun bagi hasil dalam ukuran yang luas sehingga menimbulkan berbagai persoalan ekonomi dan sosial bagi masyarakat pedesaan. Kond isi demikian bertolak belakang dengan Pasal 7 UUPA junto Pasal 10 ayat (1) dan Pasal 53 ayat (1) yang mengatur bahwa kepemilikan dan penguasaan tanah tidak diperbolehkan melampaui batas.

Sementara itu di perkotaan, penguasaan tanah secara besar-besaran oleh para pengembang besar mengakibatkan tersisihnya para pengembang kecil. Monopoli penguasaan tanah ini juga menimbulkan peluang untuk mematok harga jual tanah setinggi-tingginya. Akibatnya, harga jual rumah di perkotaan semakin tak terjangkau oleh kelompok masyarakat dengan kemampuan ekonomi menengah ke bawah.

Kondisi semacam itu tidak boleh dibiarkan berlarut-larut, mengingat kebutuhan akan tanah dan rumah tidak dapat digantikan dengan hal lain. Oleh karena itu perlu adanya intervensi pemerintah dalam upaya mencari keseimbangan dari berbagai kepentingan tersebut.

\section{Berkembangnya Pembangunan dan Ber- kurangnya Persediaan Tanah}

Pada sebagian kelompok masyarakat, tanah ditempatkan secara seimbang antara fungsi sosial dan ekonomisnya, baik sebagai sumber hidup maupun sebagai tempat tinggal. Penguasaan tanah semata-mata untuk memenuhi kepentingan-kepentingan tersebut. Sedangkan pada kelompok masyarakat yang lain, tanah hanya dilihat dari sudut ekonomisnya; tanah dipandang sebagai investasi yang dapat mendatangkan keuntungan yang bersifat ekonomis. Akibatnya, mereka berusaha melakukan akumulasi penguasaan tanah yang cenderung spekulatif dan manipulatif melebihi kebutuhan sebenarnya. Perkembangan kapitalisme telah mendorong perubahan fungsi tanah yang semula sebagai salah satu faktor produksi menjadi sarana investasi.

Hal tersebut tidak terlepas dari kebijakan dasar penanaman modal yang mendorong dipacunya pertumbuhan dan pemerataan ekonomi dalam kaitannya dengan Penanaman Modal Dalam Negeri (PMDN) dan Penanaman Modal Asing (PMA). Oleh karena itu, kemudahan dan iklim investasi yang lebih baik terus menerus diupayakan, antara lain dengan menyediakan peraturan perundang-undangan yang mendukung penyederhanaan prosedur pelayanan investasi, serta sarana dan prasarana ekonomi yang memadai.

Perkembangan di atas menunjukkan semakin meningkatnya ekonomisasi nilai tanah, dan masyarakatpun cenderung mengabaikan fungsi sosial dan magis yang mendasari hubungan manusia dengan tanah. Hal ini dapat dilihat dari semakin meningkatnya harga tanah di wilayah-wilayah yang sedang membangun dan seringnya kita mendengar konflik tuntutan ganti rugi dimana satu pihak menuntut harga serendah-rendahnya sedangkan pihak lain menghendaki harga setinggitingginya.

Prinsip-prinsip pertanahan dalam UUPA Pasal 1 ayat (2) dan (3) menjelaskan bahwa tanah di wilayah Indonesia merupakan milik bersama seluruh bangsa:

"Seluruh bumi, air dan ruang angkasa, termasuk kekayaan alam yang terkandung di dalamnya dalam wilayah Republik Indonesia sebagai Karunia Tuhan Yang Maha Esa 
adalah bumi, air dan ruang angkasa bangsa Indonesia dan merupakan kekayaan nasional."

"Hubungan antara bangsa Indonesia dengan bumi, air serta ruang angkasa termasuk dalam ayat 2 pasal ini adalah hubungan yang bersifat abadi."

Aplikasi ketentuan di atas diserahkan kepada negara agar perencanaan, penataan, peruntukan, penggunaan dan pemeliharaannya mengacu pada landasan hukum yang tunggal sehingga berdampak positif pada peningkatan kesejahteraan semua lapisan masyarakat.

UUPA Pasal 6 lebih menekankan fungsi sosial tanah dengan ketentuan bahwa "Semua hak atas tanah mempunyai fungsi sosial", sehingga penggunaan dan pengusahaannya harus dapat memberikan manfaat yang seimbang, baik baik pemiliknya maupun bagi anggota masyarakat lain, atau dengan kata lain semua penggunan hak atas tanah harus memerhatikan keseimbangan antara kepentingan individual dan kepentingan publik. Oleh karena itu, pandangan yang menempatkan tanah sebagai komoditas ekonomi semata bertentangan dengan konsep fungsi sosial tanah karena cenderung berorientasi pada keuntungan yang bersifat individual.

Berkaitan dengan masalah penguasaan tanah ini, kita juga perlu mengingat ketentuan UUPA Pasal 9 ayat (2) yang menyatakan bahwa:

"Tiap warga negara, baik laki-laki maupun wanita, mempunyai kesempatan yang sama untuk memperoleh suatu hak atas tanah serta untuk mendapat manfaat dan hasilnya, baik bagi diri sendiri maupun keluarganya".

Namun dalam pelaksanaannya,UUPA Pasal 9 ayat (2) tersebut harus terdapat tawar menawar dulu antara rakyat, pemerintah, dan pihak swasta terlebih dahulu sehingga pelaksanaan pasal di atas dapat terwujud.

\section{Dampak Liberalisasi Ekonomi Terhadap Distribusi Tanah \\ Distribusi Tanah di Pedesaan}

Intensitas pembangunan yang menuntut penyediaan tanah yang relatif luas, baik untuk pemukiman maupun untuk industri mengakibatkan terjadinya alih fungsi tanah pertanian, terutama di daerah-daerah pinggiran kota. Alih fungsi tersebut terus berlangsung, baik karena desakan ekonomi maupun karena tawaran harga tinggi dari para pengusaha yang bermaksud merubahnya menjadi tanah nonpertanian dengan nilai pendapatan ekonomis lebih tinggi.

Gejala yang sangat memprihatinkan dalam alih fungsi tanah pertanian ini sering terjadi pada beberapa daerah tingkat II yang sedang berkembang dengan pesat, misalnya Botabek (Bogor, Tenggerang, dan Bekasi) dan Sidoarjo. Hal ini menimbulkan reaksi berupa keluarnya berbagai Surat Menteri Negara Agraria/Kepala BPN serta Menteri Negara Perencanaan Pembangunan Nasional/ Ketua Bappenas sejak tanggal 15 juni 1994.

Hubungan hukum yang terkait dengan pemilikan dan penguasaan tanah pertanian pada umumnya dilakukan melalui lembaga gadai tanah atau bagi hasil, dan masih mendasarkan pada norma hukum setempat yang tidak tertulis. Dengan demikian dapat dikatakan bahwa akses terhadap hak atas tanah yang dijamin oleh undang-undang merupakan akses semu. Kondisi ini semakin diperburuk oleh praktik pemilikan tanah secara absente (guntai) dan terkadang disertai pelanggaran batas maksimal kepemilikan yang sebenarnya dilarang oleh UUPA Pasal 10 ayat (1), yaitu "setiap orang dan badan hukum yang mempunyai sesuatu hak atas tanah pertanian pada asasnya diwajibkan mengerjakan atau mengusahakannya sendiri secara efektif, dengan mencegah cara-cara pemerasan". 4

Berdasarkan ketentuan pasal di atas, maka di satu sisi jika tanah tersebut subur dan dapat dikelola secara maksimal, maka ia da-

4 Harsono, Boedi. 1999. Undang-Undang Pokok Agraria, Sejarah Penyusunan, Isi dan Pelaksanaannya (Bagian Pertama, Jilid kesatu). Jakarta: Djambatan, h. 570 . 
pat menambah pendapatan para petani, akan tetapi di sisi lain, para petani sendiri tidak dapat mengelola tanahnya karena: (a) lahan yang ada sudah tidak subur lagi/gersang, (b) tanah yang subur sudah dibeli oleh pengusaha dengan harga yang lebih tinggi, (c) hasil pertanian belum dapat dipasarkan, (d) harga beli pasar terlalu rendah sehingga merugikan para petani, dan (e) banyaknya urbanisasi. Hal ini hanya akan menguntungkan pihakpihak yang sebenarnya hidup bukan dari pertanian, atau dengan kata lain menguntungk an para penguasaha.

Setidaknya selama dua puluhan tahun terakhir ini telah terbit beberapa ketentuan dalam berbagai bentuk dan tingkatan yang pada intinya mengatur tentang alih fungsi tanah pertanian. Upaya untuk mencegah alih fungsi tanah pertanian tersebut juga dilakukan melalui kebijakan pemberian ijin lokasi disamping juga penyempurnaan terhadap Rencana Tata Ruang Wilayah (RTRW) pada beberapa Daerah Tingkat II yang terlanjur mencantumkan penggunaan tanah sawah beririgasi teknis untuk kepentingan non-pertanian. Kebijakan yang telah digariskan ini perlu diprioritaskan karena upaya pencetakan sawah untuk mengimbangi berkurangnya tanah pertanian belum dapat dilihat hasilnya.

Dengan adanya akses yang dimiliki oleh badan hukum atau perorangan yang perolehan tanahnya berdasarkan pencadangan tanah/ijin lokasi, namun tidak dimanfaatkan sesuai dengan peruntukannya sehingga akses rakyat terhadap tanah berkurang, adalah wajar untuk mengharapkan hasil investarisasi penguasaan tanah tersebut sesuai dengan Instruksi Menteri Agraria/Kepala BPN tanggal 19 Januari 1994 sambil menunggu hasilnya berupa penertiban yang konkret.

Sebenarnya kesempatan untuk melakukan komunikasi efektif dapat dilakukan apabila konstelasi hubungan suatu masyarakat dengan tanah mereka dapat dipahami secara utuh. Dengan demikian masyarakat setempat semakin terbuka menerima hal-hal baru yang positif dan bermanfaat. Cara yang ditempuh bukanlah paksaan, melainkan dengan jalan mengakui keberadaan dan menghormati hakhak mereka. Perlu kita pahami pula bahwa dikeluarkannya suatu wilayah (enclave) yang secara nyata telah dimiliki oleh suatu masyarakat hukum merupakan hal yang wajar untuk menghindari tumpang tindih penguasaan tanah.

Pendekataan yang dilakukan oleh pihak luar tidak akan mengalami hambatan apabila dilakukan dengan cara yang sesuai dengan kelaziman masyarakat yang bersangkutan. Peningkatan kesadaran masyarakat akan arti penting kepastian hukum terhadap hak atas tanahnya seharusnya mendorong upaya-upaya tersebut. Apabila untuk berbagai kegiatan di atas, tanah yang dikuasai oleh badan-badan hukum memiliki kepastian hukum, maka demikian pula halnya dengan tanah milik masyarakat setempat, sehingga keadilan dapat benar-benar dirasakan.

\section{Distribusi Tanah di Perkotaan}

Permintaan akan tanah terutama di perkotaan, tidak saja datang dari pemerintah untuk membangun prasarana dan fasilitas umum, tetapi juga dari dunia usaha maupun perseorangan. Peningkatan kebutuhan atas ketersediaan tanah menurut Sidik, antara lain disebabkan oleh: pertama, pertumbuhan jumlah penduduk, baik yang terjadi secara alamiah maupun yang disebabkan oleh urbanisasi; kedua, pertumbuhan ekonomi yang cukup tinggi, sehingga diperlukan ketersediaan tanah untuk sarana pengembangan kegiatan usaha bagi badan usaha/perusahaan, baik perusahaan lokal maupun perusahaan asing; ketiga, kenaikan tingkat pendapatan yang menaikkan "willingness to pay" terhadap kebutuhan atas tanah; keempat, terbatasnya persediaan tanah di daerah perkotaan yang siap bangun, karena kota telah menjadi pusat segala kegiatan dan daya tarik tersendiri bagi masyarakat desa, sehingga urbanisasi yang cukup tinggi semakin mengurangi lahan-lahan yang siap bangun. ${ }^{5}$

Kelemahan dalam menerapkan manajemen perkotaan tampak dari meningkatnya harga tanah yang mendorong timbulnya spekulasi, kelangkaan pengembangan tanah perkotaan untuk pemukiman, serta menjamurnya

\footnotetext{
${ }^{5}$ Sidik, h. 14
} 
pemukiman liar. Pada umumnya, tanah perkotaan diperoleh melalui proses alih fungsi tanah pertanian, baik yang dilakukan oleh pemerintah maupun pihak swasta. Manajemen pertanahan yang efisien perlu didukung oleh sistem informasi pertanahan yang handal untuk mengatur penggunaan tanah secara optimal.

Dalam bidang pembangunan perumahan, naiknya harga tanah sebagai dampak liberalisasi ekonomi sangat dirasakan, terutama oleh pengembang kecil. Ketidakmampuan bersaing dalam membeli tanah membuat mereka tersisih dan terpaksa memilih lokasi-lokasi yang kurang strategis. Akibatnya pembangunan rumah-rumah sederhana untuk masyarakat berpendapatan rendah berada di lokasi yang jauh dari tempat kerjanya. Sebaliknya, pengembang besar yang mampu membeli tanah dengan harga tinggi berusaha mengembalikan investasinya dengan cara mencari keuntungan sebesar-besarnya melalui pengembangan rumah mewah, perkantoran atau pusat perbelanjaan mewah. ${ }^{6}$

Liberalisasi ekonomi juga mendorong perubahan fungsi tanah, yaitu dari fungsinya sebagai salah satu faktor produksi utama menjadi sarana investasi. Bagi investor, investasi dalam bentuk pemilikan/penguasaan tanah dipandang sangat mengutungkan karena sebagai investasi jangka panjang tanah menjanjikan keamanan, kepastian pendapatan, nilai/harga tinggi, dan umumnya terhindar dari inflasi. ${ }^{7}$ Oleh karena itu untuk mengurangi dampak kenaikan harga dan menjaga kesinambungan usaha hingga jangka waktu yang lama, pengembang besar berusaha menguasai tanah seluas mungkin, yang sebenarnya bertentangan dengan ketentuan UUPA pasal 7: "Untuk tidak merugikan kepen-

\footnotetext{
${ }^{6}$ Suyono, 1995. Peranan dan Strategi Pengembangan Tanah (Land Developers) dan Birokrasi dalam Mengantisipasi Dampak Liberalisasi Ekonomi Terhadap Penguasaan Tanah Terutama Untuk Pemukiman Berskala Besar. Makalah Seminar Nasional Kebijakan Pertanahan dan Liberalisasi Ekonomi, Fakultas $\mathrm{Hu}$ kum, UGM, Yogyakarta, h. 3.

7 Cahyono, Bambang Tri. 1991. Dimensi Ekonomi Pembangunan Desa dan Masalah Pembebasan Tanah, Makalah Diskusi PAU-SS-UGM, Yogyakarta, h. 4.
}

tingan umum maka pemilikan dan penguasaan tanah yang melampui batas tidak diperkenankan." Dengan demikian para pengembang sebenarnya dapat merekayasa daya saing proyeknya dengan membangun berbagai fasilitas bermutu baik, seperti perbelanjaan, rekreasi, pendidikan, dan kesehatan, dimana semua itu akan menjadi beban pembeli melalui harga jual yang tinggi. Sebenarnya ketentuan mengenai pemilikan maksimum tanah di perkotaan telah diisyaratkan oleh Undang-Undang Nomor 56 Tahun 1960, yang pengaturannya lebih lanjut dijabarkan melalui Peraturan Pemerintah Daerah (Perda), namun hingga kini Perda yang mengaturnya belum juga diterbitkan.

Kondisi tersebut diantisipasi Pemerintah dengan melakukan deregulasi melalui debirokratisasi untuk lebih menggiatkan usaha swasta dan menarik masuknya modal asing. Pemerintah juga telah mengambil langkahlangkah untuk mengurangi dampak negatif dalam bidang permukiman melalui UndangUndang Nomor 4 Tahun 1992 yang di dalamnya diatur tentang konsep pembangunan perumahan dan permukiman skala besar melalui pembangunan Kawasan Siap Bangun (KSB) dan Lingkungan Siap Bangun (LSB) yang berdiri sendiri. Ketentuan-ketentuan tersebut kemudian dilengkapi dengan ketentuan tentang pembangunan perumahan dan permukiman dengan lingkungan hunian berimbang, yaitu: konsep 1:3:6 yang mewajibkan setiap pengembang rumah mewah untuk membangun tiga atau lebih rumah menengah, dan enam atau lebih rumah sederhana untuk setiap rumah mewah yang dibangun. Pengembang yang akan membangun rumah menengah tanpa rumah mewah diwajibkan membangun dua atau lebih rumah sederhana. Konsep ini dituangkan dalam Keputusan Bersama Menteri Dalam Negeri, Menteri Pekerjaan Umum dan Menteri Negeri Perumahan Rakyat pada tanggal 16 Nopember 1992.

Pengelolaan Kawasan Siap Bangunan (KSB) dilakukan oleh BUMN atau badan lain yang dibentuk dan diberi tugas oleh pemerintah. Pelepasan hak atas tanah dalam KSB yang berbentuk kapling tanah matang hanya dapat dilakukan oleh BUMN atau badan lain 
yang ditunjuk. Dengan demikian diharapkan kegiatan para spekulan dapat dikendalikan.

Pengelola KSB juga dapat menyelenggarakan usaha subsidi silang dalam penjualan kembali tanah siap bangun. Tanah komersial serta tanah untuk rumah mewah dan menengah dapat dijual kepada pihak pengembang dengan harga yang tinggi agar sebagian dari keuntungannya dapat digunakan untuk mensubsidi harga tanah untuk pembangunan rumah sederhana dan sangat sederhana. Dengan demikian untuk setiap golongan penghasilan dapat memiliki tanah yang sesuai dengan daya beli mereka.

Sedangkan LSB yang berdiri sendiri, penyelenggaraan pengelolaannya dilakukan oleh badan usaha swasta yang bergerak di bidang perumahan, namun tidak diperkenankan menjual tanah siap bangun. Mereka hanya diperbolehkan menjual kapling tanah matang dengan bangunan rumahnya, kecuali kapling tanah matang ukuran kecil dan sedang. Berbeda dengan penyelenggara pembangunan KSB yang cukup hanya membangun jaringan prasarana lingkungan primer dan sekunder sebelum dapat menjual tanah siap bangun kepada pengembang, penyelenggara pembangunan LSB yang berdiri sendiri harus membangun seluruh jaringan prasarana yang dibutuhkan sebelum menjual rumah dan kapling tanah matang ukuran kecil dan sedang.

Walaupun sudah diupayakan cara pandanaan berupa subsidi silang, namun harga tanah yang relatif tinggi mengakibatkan harga jual perumahan sederhana tidak terjangkau oleh mereka yang berasal dari kelompok yang sebenarnya sangat membutuhkan. Oleh karena itu diperlukan upaya pengendalian berupa batas waktu penyelesaian dengan sanksi tertentu terhadap kelalaian yang terjadi. Tan-

\section{DAFTAR PUSTAKA}

Abdurahman, 1991. Masalah Pencabutan Hak-Hak Atas Tanah dan Pembebasan Tanah di Indonesia Bandung: Citra Aditya Bakti. pa ada batas waktu tersebut pembangunan perumahan sederhana mungkin akan selalu tertunda, bahkan terabaikan.

Penerapan konsep KSB dan LSB yang berdiri sendiri bertujuan mewujudkan pemerataan pembangunan dan hasil-hasilnya untuk seluruh lapisan masyarakat. Azas kekeluargaan sebagaimana dimaksudkan pada UUD 1945 Pasal 33 ayat (1), yaitu "segala bumi, air dan kekayaan alam yang terkandung di dalamnya dikuasai oleh negara," tercermin dalam pembangunan KSB dan LSB yang berdiri sendiri, di mana pengembang besar, pengembang kecil dan masyarakat, baik para pemilik tanah maupun konsumen dapat bekerja sama.

Pengaturan pengelolaan KSB dan LSB yang berdiri sendiri sebagaimana diatur dalam Undang-Undang Nomor 4 Tahun 1992 merupakan pelaksanaan UUD 1945 Pasal 33 ayat (1), yaitu "segala bumi, air dan kekayaan alam yang terkandung di dalamnya dikuasai oleh negara." Dengan demikian tanah untuk perumahan dapat dinikmati pula oleh orang miskin tanpa mengurangi kesempatan para pengusaha untuk melakukan usahanya.

\section{Penutup}

Berdasarkan uraian di atas dapat disimpulkan bahwa liberalisasi ekonomi dengan distribusi penguasaan tanah yang timpang akan memunculkan dampak-dampak yang merugikan rakyat, khususnya petani. Penguasaan tanah untuk industri dan pemukiman berskala besar telah memaksa alih fungsi tanah pertanian dengan segala konsekuensinya. Dalam hal ini diperlukan sikap yang tegas dari pemerintah dalam menegakkan kebijakan korektif untuk pengendaliannya.

Cahyono, Bambang Tri. 1991. Dimensi Ekonomi Pembangunan Desa dan Masalah Pembebasan Tanah, Makalah Diskusi PAU-SS-UGM, Yogyakarta.

Harsono, Boedi. 1999. Undang-Undang Pokok Agraria, Sejarah Penyusunan, 
Isi dan Pelaksanaannya (Bagian I, Jilid I). Jakarta: Djambatan.

1971. Undang-Undang Pokok Agraria, Sejarah Penyusunan, Isi dan Pelaksanaannya (Bagian II, Jilid I). Jakarta: Djambatan.

Suyono, 1995. Peranan dan Strategi Pengembangan Tanah (Land Develo- pers) dan Birokrasi dalam Mengantisipasi Dampak Liberalisasi Ekonomi Terhadap Penguasaan Tanah Terutama Untuk Pemukiman Berskala Besar. Makalah Seminar Nasional Kebijakan Pertanahan dan Liberalisasi Ekonomi, Fakultas $\mathrm{Hu}$ kum, UGM, Yogyakarta. 